\title{
Strategy oriented to strengthen the college work of teachers for the benefit of the consolidation of Academic Corps
}

\section{Estrategia orientada a fortalecer el trabajo colegiado de los profesores en beneficio de la consolidación de los Cuerpos Académicos}

\author{
PALOMARES-RUIZ, María Blanca*†, TORRES-BUGDUD, Arturo, DIMAS-RANGEL, María Isabel
} and SORDIA-SALINAS, Cesar

Universidad Autónoma de Nuevo León, Facultad de Ingeniería Mecánica y Eléctrica

ID $1^{\text {st }}$ Author: María Blanca, Palomares-Ruiz / ORC ID: 0000-0002-4079-6969, Researcher ID Thomson: S-4843-2018, CVU CONACYT ID: 339594, arXiv ID: Mabe_6708

ID $1^{\text {st }}$ Coauthor: Arturo, Torres-Bugdud / ORC ID: 0000-0003-2214-9394, CVU CONACYT ID: 216332

ID $2^{\text {nd }}$ Coauthor: María Isabel, Dimas-Rangel / ORC ID: 0000-0001-9450-8080 Researcher ID Thomson: S-4720-2018 CVU CONACYT ID: 374045

ID $3^{\text {rd }}$ Coauthor: Cesar, Sordia-Salinas / ORC ID: 0000-0003-2186-1080, Researcher ID Thomson: S-5666-2018, CVU CONACYT ID: 339888

DOI: $10.35429 / J H R T .2020 .18 .6 .1 .5$

Received: June 30, 2020; Accepted: December 20, 2020

\begin{abstract}
The present work aims to show a strategy aimed at strengthening the academic staff through the creation of collegiate work groups which in the Mexican context are called Academic Corps (CA); the foregoing based on its strategic planning, collegiate work, relevance of the members of the CA, as well as the impact of its Lines of Generation and Application of Knowledge (LGAC) in the Educational Programs of the Faculty of Mechanical and Electrical Engineering, for which which proposes an academicadministrative structure that favors institutional achievements through the elevation of its indicators, where in the first instance a detailed analytical method of how many full-time professors participate in $\mathrm{CA}$ and the description of their LGAC, historical of academic corps by educational program and in what degree of consolidation they are found, in conclusion, different strategies were implemented promoting the increase of consolidated and consolidating academic corps , and their dissemination through means of recognized prestige at national and international level, combined to the degree of empowerment of its members, evidence of joint work and integration ration of thematic networks of collaboration.
\end{abstract}

Academic Corps, Collegiate work, AcademicAdministrative strategy

\begin{abstract}
Resumen
El presente trabajo tiene como objetivo mostrar una estrategia orientada al fortalecimiento de la planta académica mediante la creación de grupos de trabajo colegiado a la cuál en el contexto mexicano se les denomina Cuerpos Académicos (CA); lo anterior en base a su planeación estratégica, trabajo colegiado, pertinencia de los integrantes del CA, así como el impacto de sus Líneas de Generación y Aplicación del Conocimiento (LGAC) en los Programas Educativos de la Facultad de Ingeniería Mecánica y Eléctrica, para lo cual se propone una estructura académico-administrativa que lo favorece a logros institucionales a través de la elevación de sus indicadores, donde en primer instancia se efectuó un método analítico detallado de cuántos profesores de tiempo completo participan en CA y la descripción de sus LGAC, histórico de cuerpos académicos por programa educativo y en qué grado de consolidación se encuentran, en conclusión, se implementaron diferentes estrategias propiciando el incremento de cuerpos académicos consolidados y en consolidación, y su difusión a través de medios de reconocido prestigio a nivel nacional e internacional, aunado a el grado de habilitación de sus integrantes, evidencia del trabajo conjunto y la integración de redes temáticas de colaboración.
\end{abstract}

Cuerpos Académicos, Trabajo colegiado, Estrategia Académico-Administrativa

Citation: PALOMARES-RUIZ, María Blanca, TORRES-BUGDUD, Arturo, DIMAS-RANGEL, María Isabel and SORDIASALINAS, Cesar. Strategy oriented to strengthen the college work of teachers for the benefit of the consolidation of Academic Corps. Journal of Human Resources Training. 2020, 6-18: 1-5

*Correspondence to Author (mbpalomares@yahoo.com.mx)

$\dagger$ Researcher contributing first Author 


\section{Introduction}

A higher level Educational Institution committed to providing innovation and scientific and technological development to society based on the constant changes in the needs of the national and international industry through the planning and implementation of specific strategies according to the Educational Program (PE) and under an educational model based on competencies. Given this, in the Faculty of Mechanical and Electrical Engineering (FIME), which is a dependency of the Autonomous University of Nuevo León, the need arises to form research groups that allow the professor to consciously think and put into practice the development of their academic skills with it. provide continuous improvement to PEs.

Within the Mexican national framework there is the Secretary of Higher Education, which through the Directorate of Academic Improvement (DSA) and the Program for Teacher Professional Development (PRODEP), formerly the Teacher Improvement Program (PROMEP), have the objective of contributing to that the Full Time Professors (PTC) of the Public Institutions of Higher Education achieve the capacities to carry out the substantive actions of a Quality Teacher: Teaching, Knowledge Generation, Academic Management-Linkage, and Tutoring, in addition they are articulated and consolidated in academic corps .

The Academic Corps (CA) are groups of full-time professors who share projects, activities or studies that deepen their knowledge as a product of basic and applied research with academic objectives and goals, in disciplinary or multidisciplinary subjects to which that PRODEP defines as Line (s) of Generation or Innovative Application of Knowledge (LGAC) as mentioned in its Operating Rules 2018 (DSA, 2017).

Due to the above and due to the impact that these research groups have on the present work, an academic-administrative structure is shown that allows to consolidate the research and management strategies, in order to strengthen the collegiate work of the Professors with the purpose of contributing positively to competitiveness and academic ability.
Likewise, encourage these research groups to be articulated in CA formed based on their strategic planning, relevance among their members, as well as the impact of their LGAC on Educational Programs.

\section{Background}

In order to strengthen collaborative work among professors who belong to universities and higher education institutions, the creation and consolidation of academic corps has been promoted, which include different areas of knowledge depending on the characteristics of the institutions and agencies, Currently at the national level there are 6107 Academic Corps distributed in the different Subsystems of Higher Education of the Country.

For the state of Nuevo León, the participation of each teacher is crucial in the teaching-learning process, and each of them must contribute greatly to a quality education, which is why this year registered a total of 268 Academic Corps which represents $4 \%$ of the national total. In this sense, the UANL, according to the policies formulated for the development and consolidation of the Academic Corps as a central axis in the generation and application of knowledge, contributes with 98\% of the Academic Corps at the State level, which it is worth mentioning is made up of 61 Higher Education Units (DES) in which a total of 263 Academic Corps are distributed.

For its part, the FIME, as a higher education unit of the UANL, has managed to increase the amount of CA in the different areas of knowledge, in accordance with the strategies embodied in its Development Plan, so that by 2020 it has 40 Academic Corps, which represents an indicator of $70 \%$ in their degree of consolidation, of which 12 are in formation (CAEF), 14 are in consolidation (CAEC) and 14 are consolidated (CAC).

The behavior of this indicator in recent years makes evident an important closing of quality gaps between Academic Corps, highlighting above all the significant growth in the number of CAC and CAEC Corps, as shown in graph 1. 


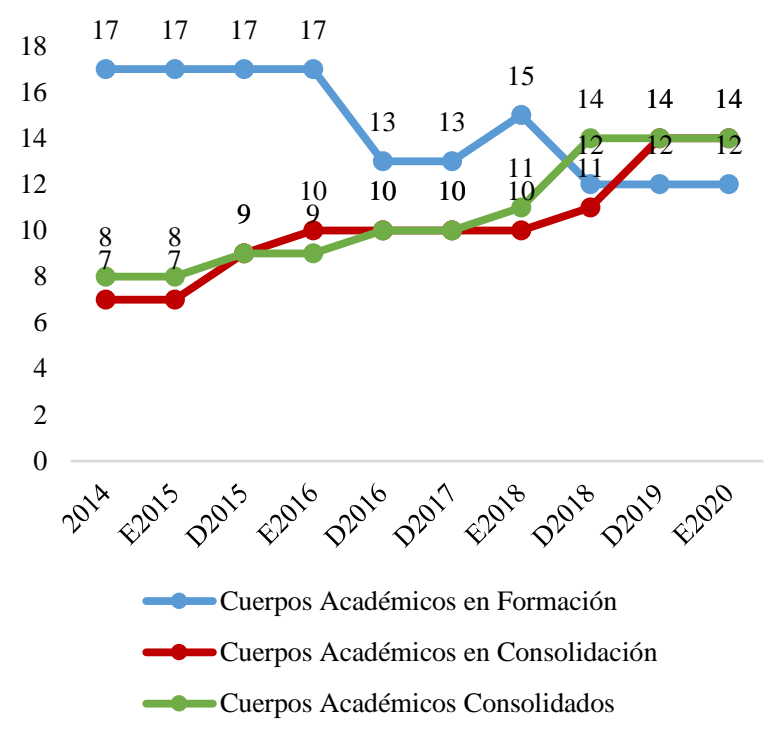

Graphic 1 Academic Corps at FIME, UANL Own Elaboration

\section{Theoretical framework}

In order to train quality students who contribute to the economic development of the country, the Academic Corps are made up of groups of professors belonging to an IES who have a full time of dedication in conjunction with teaching activities, research, academic-administrative management, tutoring and advisory; They are categorized by their degree of consolidation determined by the maturity of the LGACs that they develop jointly from the common goals established by the members.

López (2010) quotes Olivé (2008) when pointing out that:

"The objective of scientific communities is to generate authentic knowledge in their field, an objective knowledge of reality that is the result of rational processes ... scientific communities are characterized by a constellation of shared elements, including prior knowledge that they accumulated in their field, but, above all, a set of common values and interests within each specialty".

López (2010) mentions that the work teams reported:

\footnotetext{
- Products: Drafting, analysis, interpretation, integration and presentation of documents in each thematic field.

- Discussion: Regular meetings to work and analyze the thematic axes of the states of knowledge.
}

- Compilation of material: Search and classification of information on topics of interest.
Databases:
Systematization of bibliographic and documentary databases, with the support of assistants and research assistants.

The following are the characteristics to determine the degree of consolidation of a CA in accordance with PRODEP:

\section{CAEF:}

- $\quad$ The members have defined the LGAC they cultivate.

- $\quad$ The CA has joint research projects to develop the LGAC / LIIADT / LILCD.

- $\quad$ The CA has its members identified.

- $\quad$ The CA has identified some related highlevel CAs from other institutions in the country or abroad with whom they wish to establish contacts.

\section{CAEC:}

- The CA has academic products recognized for their good quality and derived from the development of the LGAC / LIIADT / LILCD that they cultivate.

- Members participate jointly in welldefined LGAC / LIIADT / LILCD.

- At least a third of its members have extensive experience in teaching and training of human resources.

- $\quad$ Most of the members have recognition of the desirable profile.

- $\quad$ The CA has objective evidence regarding its collegiate life and the academic actions carried out in collaboration with its members.

- $\quad$ The CA collaborates with other CAs.

CAC:

- The CA has academic products recognized for their good quality and derived from consolidated LGAC / LIIADT / LILCD.

- $\quad$ The members of the CA have extensive experience in teaching and training of human resources.

- $\quad$ Most of the members have the Desirable Profile Recognition, they have a high commitment to the institution, they collaborate with each other and their production is evidence of this. (DSA, 2017)

PALOMARES-RUIZ, María Blanca, TORRES-BUGDUD, Arturo, DIMAS-RANGEL, María Isabel and SORDIA-SALINAS, Cesar. Strategy oriented to strengthen the college work of teachers for the benefit of the consolidation of Academic Corps. Journal of Human Resources Training. 2020 


\section{Methodology}

Based on an analytical method, a documentary research work was carried out, which consists of separately reviewing all the necessary material collection (Maya, 2014) to determine a strategy for the Creation and Transition of Academic Corps, based on the PE graduation profiles considering the CA's LGAC as the development engine of Educational Programs, the foregoing based on a 3-year development plan and annual operational planning; I consider this stage a strategic stage

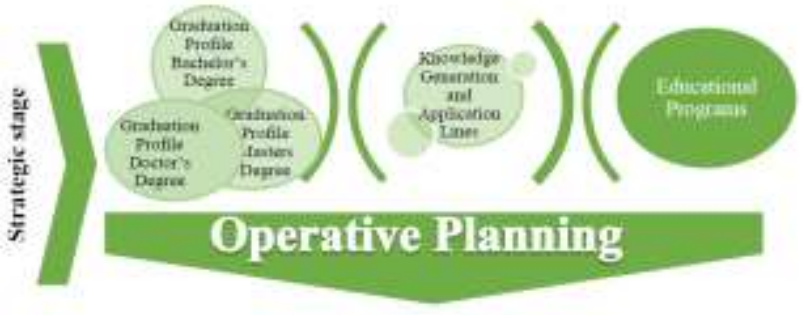

Figure 1 Strategic Stage

Own Elaboration

As an operational stage, the administrative processes for the creation of Academic Corps were implemented where, in the first instance, the graduation profiles were aligned with the Knowledge Generation and Application Lines to later launch an internal call based on the needs of the PEs, where in addition to the formats established by PRODEP and the operating rules of the same organization, documentation of a development plan is requested which suggests a SWOT analysis of the characteristics of each of the consolidation categories in order to move forward in the next 3 years . In addition to the updated Curriculum Vitae of each member, as well as a representative sample of the academic production linked to the LGAC (s) to be cultivated.

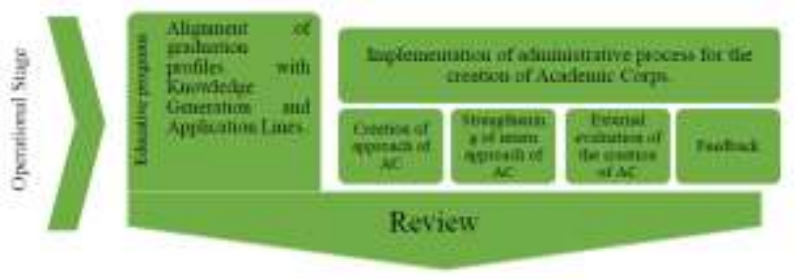

Figure 2 Operational Stage Own Elaboration
In a second stage, and in collaboration with a committee of recognized CA leading professors, members of the National System of Researchers (SNI), and with mastery of the calls made by PRODEP, an internal evaluation is carried out that allows issuing recommendations based on to its collegiate work and relevance as a working group that shares projects, activities or studies that deepen knowledge, as well as experience as evaluators both PRODEP and the National Council of Science and Technology (CONACyT) to later provide feedback with the objective of strengthen said proposals to finally obtain the impact and relevance of the creation of new ACs or their transition by strengthening the PEs through their LGACs.

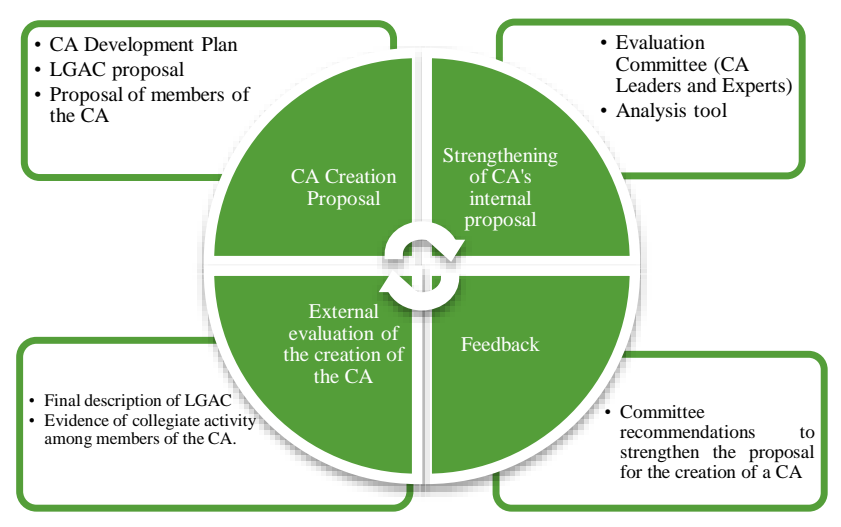

Figure 3 Academic - Administrative Strategy for the Development of Academic Corps

Own Elaboration

This structure allows to be a filter so that the proposals of the academic body that want to be created or request their transition of degree of consolidation strengthen their proposal based on the recommendations made by the Evaluation Committee of Proposals for Creation and Transition of CA, and in this way have a better chance of success.

\section{Results}

Aware of the need to achieve high levels of educational quality, it is necessary to strengthen the academic capacity of the CAs, which is understood as raising academic qualification, intensifying collegiate life and institutional commitment, as well as participation in collaboration and exchange networks academic staff of the institution. 
For this, the analysis of the importance of academic corps and their impact on student society, in relation to educational programs; which all dependencies must have academic corps among their teaching staff with the goal of improving and strengthening their teaching methods, successfully transmitting their knowledge and promoting research.

Next, the increase that has occurred from the implementation of the academicadministrative strategy for the development of the Academic Corps is shown, where it is evident that in addition to the evolution in quantity of $\mathrm{CA}$, the transition from $\mathrm{CAEF}$ to CAC and CAEC.

Similarly, it can be noted that a total of 187 PTC are members of a CA, who contribute integrally to the mission of the educational institution, since the comprehensive work they carry out positively impacts the development of engineering students, which represents $44 \%$ of the Full-time academic staff at FIME.

The strengthening of the substantive actions has favored the level of awareness of the professors in relation to their institutional commitment of the Professors who contribute to the transition of the degree of Consolidation of the Academic Corps.

\section{Conclusions}

With the strategy presented in this work, the impact of the internal call for teachers who wish to create or request the transition of degree of consolidation of an Academic Body is evidenced, with this it is intended to promote greater participation and strengthening of their CAs, without However, every effort that is made is with the intention of contributing to the comprehensive training of students and at the same time obtaining improvements in the Academic Capacity of the Unit, since there is the possibility that they will be decreased by various factors, among others that the PTC with more seniority they retire, fulfilling their cycle, so the training must be permanent with a greater focus on the new PTCs on the importance of creating and strengthening the CAs.

\section{References}

DSA. (27 de diciembre de 2017). Reglas de Operación del PRODEP 2018. Obtenido de http://www.dgesu.ses.sep.gob.mx/Documentos/ DSA\%20gobmx/Prodep_S247.pdf

DSA. (31 de ENERO de 2019). Cuerpos académicos reconocidos por PRODEP. Obtenido de https://promep.sep.gob.mx/ca1/Conceptos2.htm 1

FIME. (2012). Plan de Desarrollo FIME 2012$2020 . \quad$ Obtenido de http://www.fime.uanl.mx/Plan\%20de\%20desarr ollo\%20FIME\%20Vision\%202020.pdf

Lopez Leyva, S. (2010). Cuerpos académicos: factores de integración y producción de conocimiento. Revista de la Educación Superior, 7-25.

Maya, E. (2014). Métodos y técnicas. México: Universidad Nacional Autónoma de México.

UANL. (29 de MARZO de 2012). Plan de Desarrollo Institucional UANL 2012-2020. Obtenido de http://www.uanl.mx/sites/default/files/documen tos/universidad/pdi-2020-26abril.pdf 